\title{
Rancang Bangun STIKI Class Facilities E-Complaint
}

\author{
Ni Kadek Ariasih ${ }^{1}$, I Made Gede Sri Artha² \\ Manajemen Teknologi Informatika, STIMIK STIKOM INDONESIA \\ Jl. Tukad Pakerisan 97 Denpasar, Bali \\ 1adek12150927@yahoo.com \\ 2made@artha.web.id
}

\begin{abstract}
Abstrak
STMIK STIKOM Indonesia adalah salah satu institusi di bidang pendidikan yang berbasis komputer. Untuk menunjang keefektifan pelaksanaan aktifitas belajar mengajar yang berlangsung dikampus perlu didukung dengan pelayananan terhadap ketersediaan fasilitas kelas yang memadai dan juga pelayanan pengaduan keluhan jika terjadi kendala pada fasilitas yang ada di kelas. Selama ini pengelolaan pengaduan keluhan terhadap fasilitas ruangan kelas maupun di labarotorium yang ditangani oleh Pihak Tata Laksana Rumah Tangga Dan Perlengkapan maupun Bagian Teknisi masih bersifat manual. Untuk dapat mencatat dan menangani keluhan tersebut diperlukan sistem informasi yaitu STIKI Class Facilities EComplaint. Sistem ini dapat membantu Pihak Tata Laksana Rumah Tangga Dan Perlengkapan maupun Bagian Teknisi dalam memonitor keluhan dari kondisi faslitas ruangan yang ada jika mengalami kendala dan juga dapat meningkatkan kualitas pelayanan dalam menangani keluhan. Adapun model proses pengembangan perangkat lunak yang digunakan adalah model prototype dan berbasis Web dengan PHP dan database MySQL.
\end{abstract}

Kata kunci: pengaduan keluhan, Sistem Informasi, Prototype, Web, PHP, MySQL

\begin{abstract}
STMIK STIKOM Indonesia is one of the institutions in the field of computer-based education. In order to support the effectiveness of the implementation of teaching and learning activities that take place, it is need a service that support the availability of adequate class facilities and complaints services if there are constraints on facilities in the classroom. So far, the management of complaints complaints against classroom facilities or in the labarotorium which is handled by the Household Management Section is still on manua basis. In terms of record and handle complaints it is required information system which called STIKI Class Facilities EComplaint. This system can assist the Household Management Section in monitoring complaints from the condition of existing room facilities if experiencing problems and also can improve the quality of service in handling complaints. The software development process model used is prototype and Web-based model with PHP and MySQL database.
\end{abstract}

Keywords: Complaint Services, Information System, Prototype, Web, PHP, MySQL

\section{Pendahuluan}

Salah satu faktor yang menjadikan teknologi semakin dibutuhkan adalah meningkatnya akan kebutuhan informasi yang sangat beragam. Penyajian informasi yang efektif dan tepat guna akan menjadikan performa sebuah instansi/perusahaan atau organisasi semakin berkualitas. Untuk menghasilkan informasi tersebut maka dibutuhkan sebuah sistem informasi yang mendukung dalam pengolahan datanya. Seperti halnya menangani keluhan dari pelanggan jika terdapat masalah pada produk yang sudah dibeli. Proses pencatatan data keluhan dari pelanggan dan proses penggantian barang yang masih bersifat manual menyebabkan pelayanan terhadap pelanggan dirasa kurang maksimal. Untuk mencatat dan mengorganisir 
proses tersebut, maka dibutuhkan sebuah sistem informasi yang menunjang guna meningkatkan produktivitas kerja yang lebih efektif dan efesien [1].

Sistem pengelolaan pengaduan keluhan fasilitas ruangan pada STMIK STIKOM Indonesia saat ini masih bersifat manual. Dimana sistem manual yang selama ini berjalan adalah dimulai dari ketika dosen mengalami kendala terhadap fasilitas ruangan yang disediakan terjadi kerusakan.

Yang menjadi kendala adalah jika dosen ingin menyampaikan keluhan dengan posisi berada dilantai 2, 3 dan 4 harus mendatangi ruangan Pihak Tata Laksana Rumah Tangga Dan Perlengkapan yang terletak dilantai 1 . Tentu saja hal tersebut dapat mengurangi waktu mengajar jika menyampaikan keluhannya secara langsung. Hal ini mengakibatkan kegiatan belajar mengajar menjadi tidak efektif karena dapat mengurangi jam mengajar dosen. Sedangkan kendala dari Pihak Tata Laksana Rumah Tangga Dan Perlengkapan adalah pelaporan keluhan tersebut agar dapat ditangani harus megkonfirmasikan ke Bagian Teknisi. Jika Bagian Teknisi tidak ada maka diteruskan untuk mencatat keluhan tersebut ke buku keluhan. Yang kemudian dilanjutkan untuk pindah ruangan kelas lain dan tentu saja membutuhkan waktu untuk pencarian ruangan kelas yang kosong dengan fasilitas ruangan yang tidak mengalami kerusakan. Melihat permasalahan tersebut dan untuk meningkatan efisiensi dalam pelayanan sarana dan prasarana yang disediakan oleh pihak Kampus. Adapun salah satu cara yang dapat dilakukan adalah dengan membangun Sistem Informasi STIKI Class Facilities E-Complaint menggunakan model pengembangan prototype dan berbasis web. Pemilihan penggunaan model pengembangang perangkat lunak dengan prototype dan berbasis web ini bertujuan untuk mempermudah pemberian gambaran sistem dalam bentuk prototipe dan kemudahan dalam mengakses aplikasi dimana saja.

Beberapa penelitian terkait dengan pengelolaan menggunakan sistem informasi adalah Sistem Informasi Manajemen sebagai Alat Pengelolaan Penelitian Dosen, pada penelitian ini dibuat sistem informasi untuk memanajemen penelitian dosen pada STMIK STIKOM Indonesia, selain itu penelitian yang terkait adalah Analisis Dan Perancangan Sistem Informasi Pengelolaan Arsip Berbasis Web (Studi Kasus: Pada Komisi Pemilihan Umum (KPU) Kabupaten Tebo), pada penelitian ini membahas mengenai pentingnya pengelolaan arsip sesuai klasifikasi dan tempat pengarsipan berdasarkan dengan jenis dan kepentingannya, sehingga petugas tidak mengalami kesulitan dalam pencarian dokumen yang dibutuhkan [2] [3]. Sistem informasi pengelolaan arsip berbasis web yang dibuat dapat mempermudah kerja petugas dalam melakukan pengelolaan dan pencarian arsip. Penelitian lainnya adalah Perancangan Sistem Informasi Manajemen Modul Layanan Pada Rumah Sakit, pada penelitian ini penggunaan sistem informasi untuk memudahkan dokter untuk melihat rekam medis pasien [4]. Penelitian mengenai pentingnya sistem informasi dijelaskan pada artikel Management Information System To Help Managers For Providing Decision Making In An Organization, disini dijelaskan mengenai SIM menyediakan informasi yang akurat dan tepat waktu yang diperlukan untuk memfasilitasi proses pengambilan keputusan dan memungkinkan perencanaan, pengendalian, dan operasional organisasi secara efektif [5]. Berdasarkan penelitian tersebut STIKI Class Facilities E-Complaint diharapkan dapat memberikan informasi yang valid tentang fasilitas ruangan apakah mengalami kendala selama dosen mengajar. Sistem ini nantinya dapat menerima inputan dari dosen jika mengalami kendala terhadap fasilitas ruangan tersebut baik itu dari kerusakan yang terjadi pada Komputer, Monitor, LCD, Jaringan Internet, maupun AC. Antar muka sistem ini dapat menampilkan ruangan dalam bentuk denah yang berisikan informasi ruangan yang ternotifikasi apabila terjadi kendala pada saat dosen menginputkan keluhan tersebut, sehingga bagian teknisi dapat dengan segera menangani kerusakan peralatan yang ada dalam ruangan tersebut.

\section{Metodologi Penelitian}

\subsection{Alur Penelitian}

Penelitian dilakukan dengan merancang Sistem Informasi STIKI Class Facilities E-Complaint di STMIK STIKOM Indonesia. Penelitian ini terbagi atas beberapa langkah yang dapat dilihat pada Gambar 1 berikut ini: 


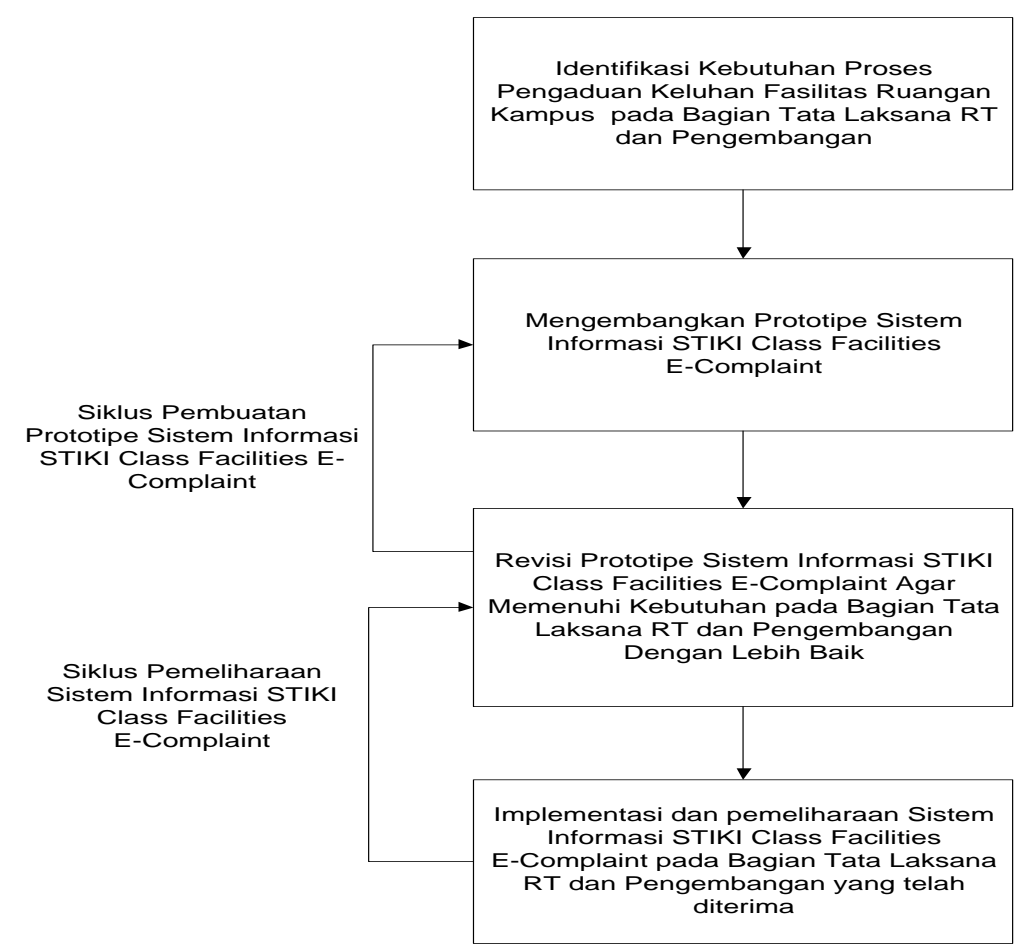

Gambar 1. Alur penelitian STIKI Class Facilities E-Complaint dengan model protype

Proses alur penelitian pada Gambar 1 diatas dapat dijelaskan sebagai berikut :

1. Identifikasi Kebutuhan Sistem

Pengumpulan kebutuhan dilakukan dengan pertemuan antara customer yaitu pihak pelaksana tata rumah tangga dan pengembagan maupun pihak teknisi dan dengan peneliti selaku pihak developer. Hal-hal yang dibahas pada pertemuan awal meliputi tujuan umum, kebutuhan yang diketahui dan gambaran bagian-bagian yang akan dibutuhkan berikutnya.

2. Mengembangkan Prototype

Setelah kebutuhan sistem terkumpul, maka mulai dikembangkan dengan merancang prototype sistem dengan cepat dan mewakili semua aspek sistem yang diketahui sehingga menjadi dasar pembuatan prototype. Tipe prototype yang dibangun adalah reusable prototype yaitu menggunakan kembali prototype yang telah dibuat untuk disempurnakan menjadi sistem yang digunakan.

3. Revisi Prototype

Pada proses ini pihak pelaksana tata rumah tangga dan pengembangan maupun pihak teknisi melakukan evaluasi prototype yang dibuat dan pihak developer. Kemudian pihak developer akan melakukan tahap revisi prototype. Proses ini akan dilakukan beberapa kali sampai customer merasa puas atas prototype yang dibangun. Ketika customer merasa puas atas prototype yang dibangun, maka kebutuhan sistem telah tergambarkan seluruhnya dan sistem siap dikembangkan menjadi perangkat lunak.

4. Implementasi dan Pemeliharaan Sistem

Perangkat lunak yang telah diterima oleh customer ini akan kembali dievaluasi beberapa kali sampai customer merasa telah sesuai dengan kebutuhan sistem yang diinginkan. Jika hasilnya telah positif maka perangkat lunak siap diimplementasikan dan sekaligus pemeliharaan sistem akan dilakukan jika aplikasi tersebut tidak mengalami revisi kembali. 


\subsection{Gambaran Umum Sistem}

Adapun gambaran Umum Sistem Informasi STIKI Class Facilities E-Complaint di STMIK STIKOM Indonesiadapat dilihat pada gambar berikut ini:

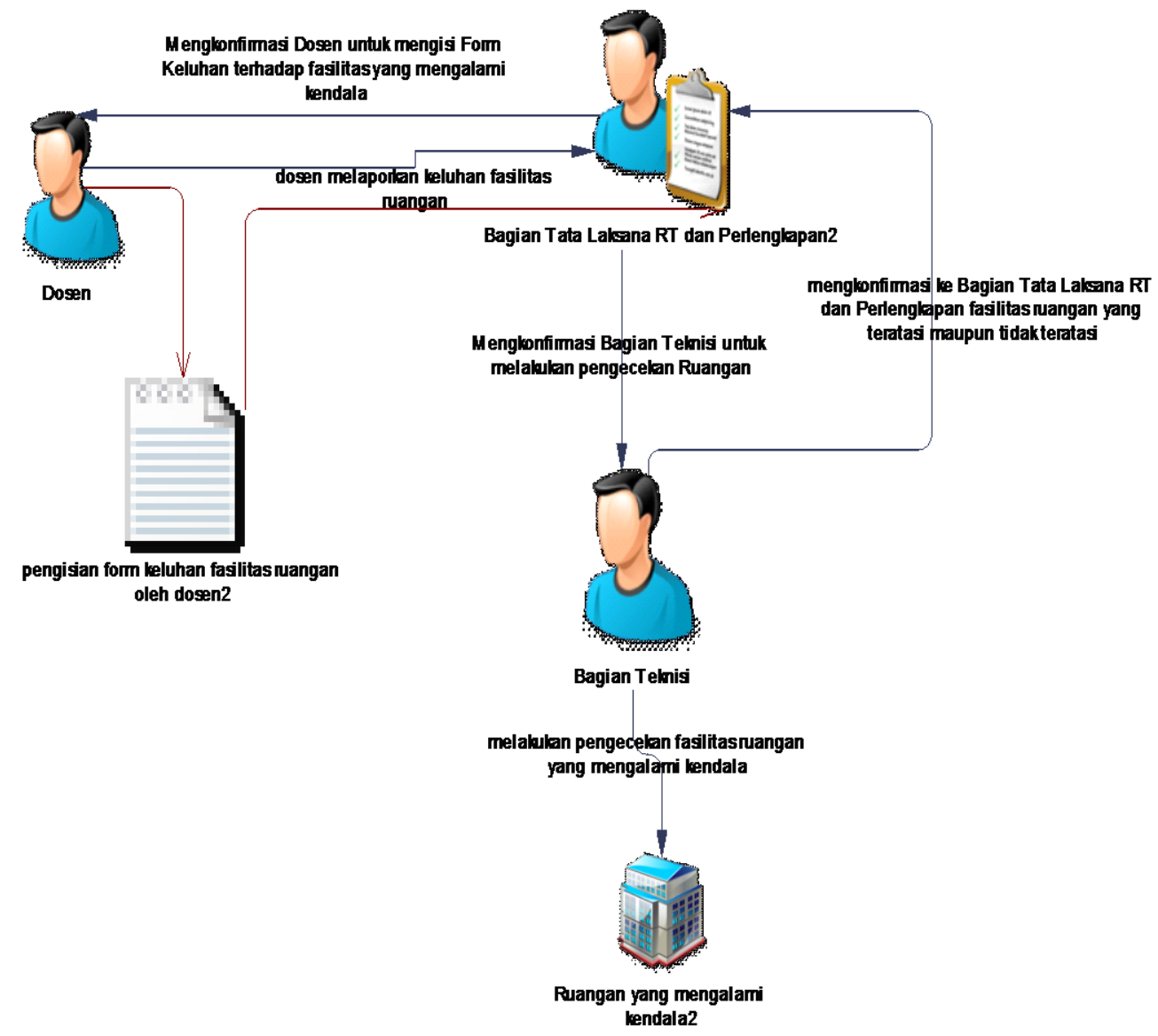

Gambar 2. Gambaran Umum Sistem Informasi STIKI Class Facilities E-Complaint

Adapun gambaran umum Sistem Informasi STIKI Class Facilities E-Complaint di STMIK STIKOM Indonesia secara garis besar dapat digambarkan sebagai berikut :

a. Dalam hal ini dosen sebagai user yang menggunakan Sistem Informasi STIKI Class Facilities E-Complaint di STMIK STIKOM Indonesia melakukan pengisian form keluhan jika terjadi kendala terhadap fasilitas yang terdapat dikelas.

b. Pihak Tata Laksana Rumah Tangga Dan Perlengkapan selaku admin notifikasi Sistem Informasi STIKI Class Facilities E-Complaint di STMIK STIKOM Indonesia, dapat melihat keluhan yang telah dikirim oleh user melalui halaman notifikasi kelas yang mengalami kendala dan selain itu juga dapat memonitoring kinerja pihak Teknisi apakah telah melakukan pengecekan terhadap kelas tersebut sehingga dapat menghapus notifikasi keluhan jika telah tertangani.

c. Pihak Teknisi selaku user yang hanya dapat melihat halaman notifikasi kelas yang mengalami kendala ataupun yang tidak mengalami kendala. Jika melihat terdapat notikasi terhadap kelas yang mengalami kendala maka akan dilakukan tindakan pengecekan dan penanganan terhadap fasilitas. 


\section{Kajian Pustaka}

\subsection{Konsep Dasar Sistem Informasi}

Informasi merupakan hal yang penting bagi manajemen dalam pengambilan keputusan. Informasi diperoleh dari sistem informasi. Sistem informasi didefinisikan oleh Robert A. Leitch dan K. Roscoe Davis sebagai berikut : "Sistem Informasi adalah suatu sistem didalam suatu organisasi yang memepertemukan kebutuhan pengolahan transaksi harian, mendukung operasi, bersifat manajerial dan kegiatan strategi dari suatu organisasi dan menyediakan pihak luar tertentu dengan laporan-laporan yang diperlukan" [6].

Sistem Informasi Berbasis Komputer (Computer Based Information System - CBIS) mengandung arti bahwa komputer memainkan peranan penting dalam sebuah sistem informasi. Lebih jelasnya, CBIS merupakan sistem pengolah data menjadi sebuah informasi yang berkualitas dan dipergunakan untuk suatu alat bantu pengambilan keputusan. Beberapa istilah yang terkait dengan CBIS antara lain adalah data, informasi, sistem, sistem informasi, dan "basis komputer" sebagai kata kuncinya [7].

\subsection{Keluhan (Complaint)}

Keluhan pelanggan merupakan salah satu saluran umpan balik yang paling praktis, yang seharusnya dapat dimanfaatkan oleh organisasi atau perusahaan untuk mengetahui respon dan tanggapan konsumen atas produk maupun jasa yang diberikan. Penanganan keluhan pelanggan yang tepat dapat membantu perusahaan mengenali kelemahan produk dan jasanya, meningkatkan kualitas dan meningkatkan kepuasan konsumen.

Penanganan keluhan pelanggan yang tidak tepat akan menjadi semacam bumerang bagi perusahaan sendiri karena pelanggan yang kecewa akan dengan cepat menyebarluaskan kekecewaan mereka, baik melalui mulut kemulut (words of mouth) ataupun melalui media, baik cetak maupun online. Penyebaran melalui media onlinelebih cepat lagi karena adanya kebebasan bagi para konsumen untuk menyatakan keluhannya tanpa harus menyertakan identitas dan biasanya pembaca cenderung mudah mempercayai keluhan tersebut [8]

\subsection{Basis Data}

Basis data adalah relasi data logical yang terdiri dari entity-entity, attribute-attribute, dan relationship dari informasi organisasi / perusahaan. Tujuan utama pengelolaan data dalam basis data adalah agar kita dapat memperoleh data yang kita cari dengan mudah dan cepat. Pemanfaatan basis data dilakukan untuk memenuhi sejumlah tujuan [9][10] seperti berikut ini :
a. Kecepatan dan kemudahan (speed)
b. Efisiensi ruang penyimpanan (space)
c. Keakuratan (accuracy)
d. Ketersediaan (availability)
e. Kelengkapan (completeness)
f. Keamanan (security)
g. Kebersamaan pemakaian (sharability)

\subsection{Metode Pengembangan Sistem Dengan Prototype}

Metode Pengembangan sistem yang digunakan adalah metode Prototype. Prototype merupakan suatu metode dalam pendekatan sistem yang digunakan untuk membuat sesuatu program dengan cepat dan bertahap sehingga segera dapat dievaluasi oleh pemakai. Tahapan-tahapan yang terdapat dalam metode Prototype [11] ini adalah sebagai berikut :

1. Identifikasi kebutuhan pemakai Pada tahapan ini pengembang dan pemakai bertemu. Pemakai menjelaskan kebutuhan sistem.

2. Membuat prototype

Pengembang mulai membuat prototype dari sistem.

3. Menguji prototype 
Setelah prototype terbentuk, pemakai menguji prototype dan memberikan kritikan atau saran.

4. Memperbaiki Prototype

Pada tahapan ini pengembang melakukan modifikasi sesuai dengan masukan dari pemakai.

5. Mengembangkan Prototype

Setelah evaluasi dilakukan dan sistem sempurna sesuai dengan keinginan pemakai. Maka pengembang merampungkan sistem sesuai dengan masukkan terakhir dari pemakai.

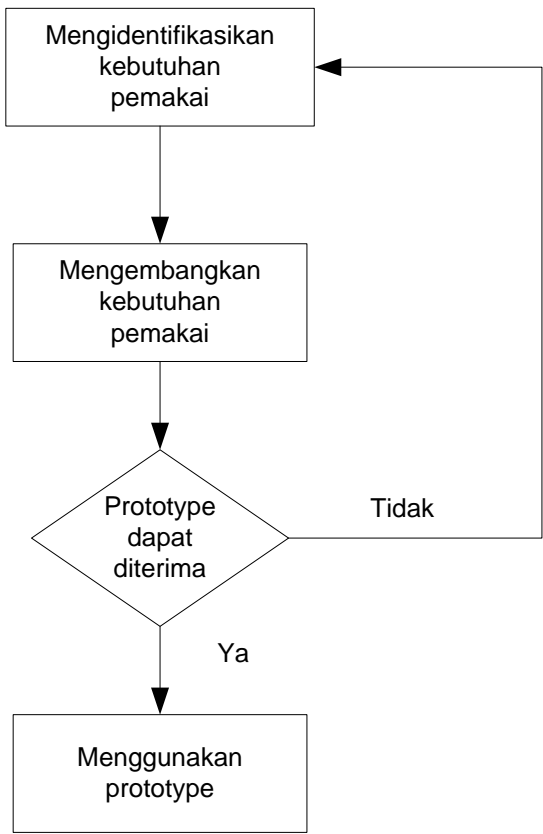

Gambar 2. Metode Prototype

\section{Hasil dan Pembahasan}

\subsection{Analisis Sistem}

Analisis sistem dilakukan untuk menentukan kebutuhan perangkat lunak dan kebutuhan perangkat keras yang digunakan, sehingga terjadi hubungan antara pembuat sistem dengan pemakai sistem. Analisa sistem meliputi, analisis kebutuhan perangkat keras dan lunak, event list dan analisis data flow diagram.

\subsubsection{Analisis kebutuhan perangkat keras dan lunak}

Pada penelitian ini, Sistem Informasi STIKI Class Facilities E-Complaint di STMIK STIKOM Indonesia dikembangkan dalam ruang lingkup Microsoft Windows. Sistem dibuat dengan menggunakan bahasa pemrograman PHP dan menggunakan DBMS (Database Manajemen System) SQLyog. Sedangkan untuk spesifikasi hardware yang digunakan untuk pengembangan sistem minimal adalah Intel pentium 4, memori RAM 1 GB of dan Hard Disk $80 \mathrm{~GB}$.

\subsubsection{Event List}

Event list merupakan daftar kejadian yang terjadi dalam lingkungan sistem dan mempunyai hubungan dengan respon yang diberikan oleh Sistem Informasi STIKI Class Facilities EComplaint. Adapun daftar kejadian dari sistem tersebut, antara lain :

1. Halaman Pengisian Keluhan/Komplain

a. Proses Keluhan/Komplain Fasilitas

b. Batal Keluhan/Komplain Fasilitas

2. Halaman Denah Ruang 
3. Halaman Daftar Keluhan Yang Belum Teratasi

a. Clear Keluhan/Komplain Fasilitas

Kebutuhan akan daftar kejadian diatas, selanjutnya akan disesuaikan untuk perancangan konteks diagram dan data flow diagram.

\subsubsection{DFD Level 0}

DFD Level 0 merupakan suatu proses yang menggamabarkan ruang lingkup suatu sistem secara keseluruhan. Gambar 3 menunjukkan DFD Level 0 untuk Sistem Informasi STIKI Class Facilities E-Complaint

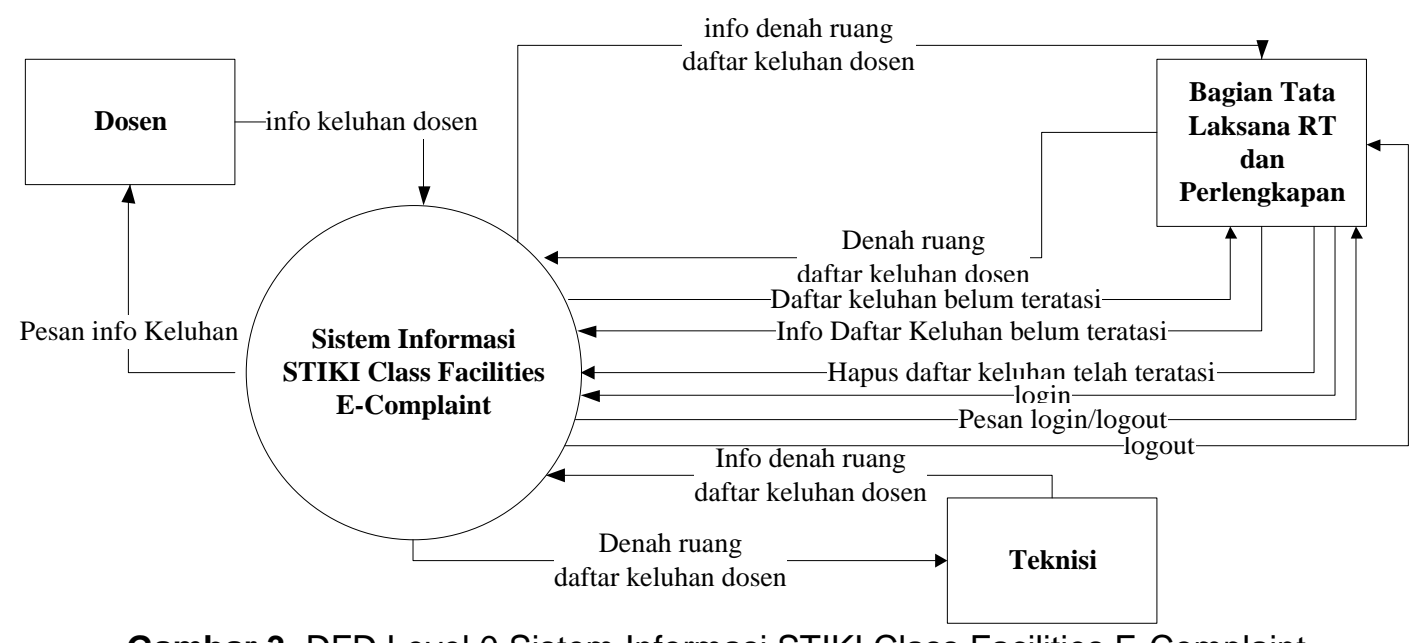

Gambar 3. DFD Level 0 Sistem Informasi STIKI Class Facilities E-Complaint

Pada Gambar 3 terdapat 3 kesatuan luar yaitu Tata Laksana Rumah Tangga dan Perlengkapan selaku Admin, Teknisi dan Dosen, dimana data Dosen, Ruangan dan User di inputkan sebelumnya pada sistem oleh admin. Pengisian data tentang keluhan atau komplain dilakukan oleh Dosen. Langkah selanjutnya adalah merancang DFD level 1, pada rancangan ini penggambaran sistem secara detail dijabarkan dengan mengacu kepada event list yang telah dijelaskan.

\subsubsection{DFD Level 1}

Pada Gambar 4 menunjukan DFD Level 1 untuk Sistem Informasi STIKI Class Facilities EComplaint sebagai berikut : 


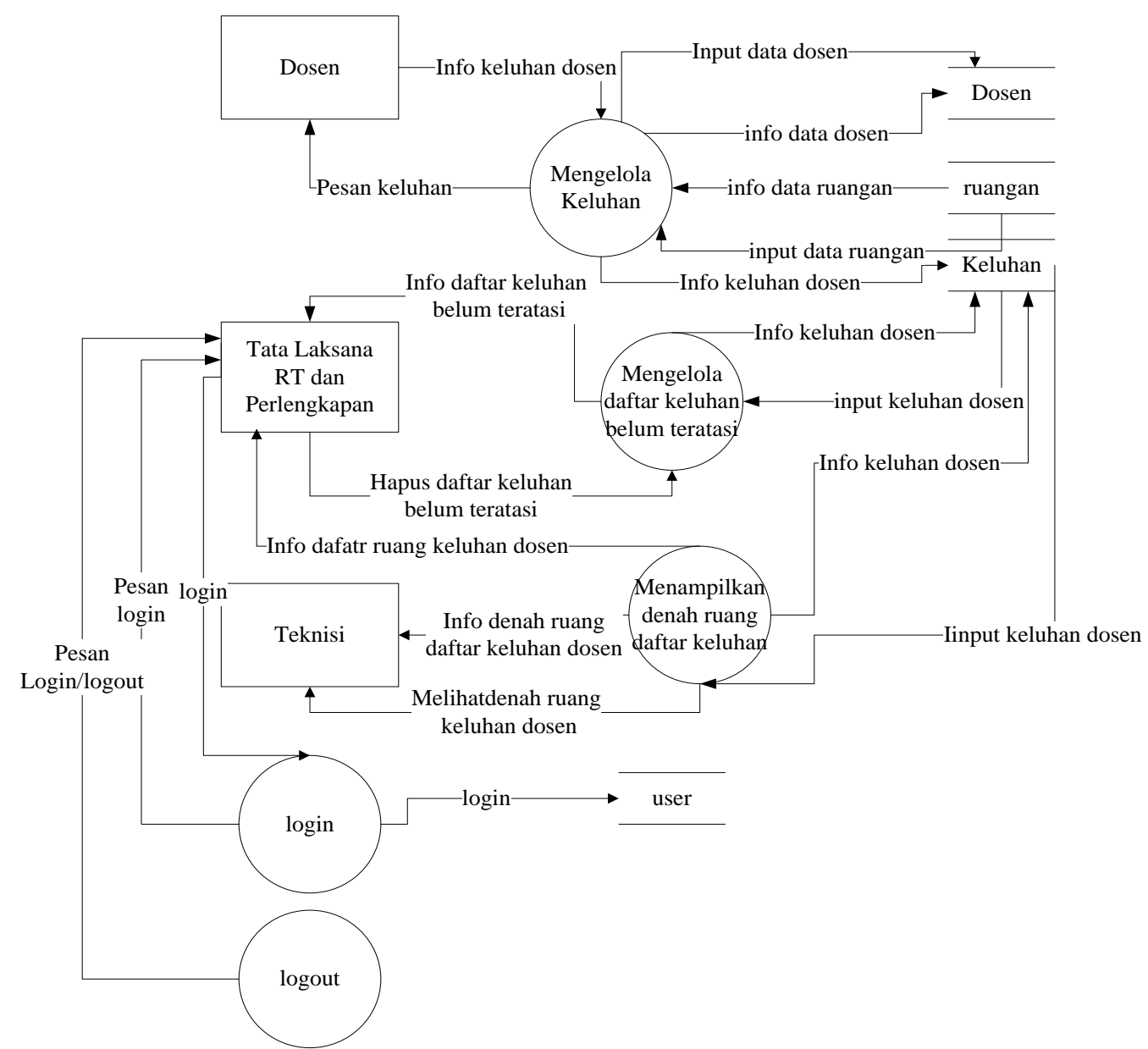

Gambar 4. DFD Level 1 Sistem Informasi STIKI Class Facilities E-Complaint

\subsection{Implementasi}

Implementasi antar muka merupakan tahapan yang dilakukan untuk mengimplementasikan hasil perancangan antar muka ke dalam bentuk sistem. Adapun tampilan antar muka sistem informasi STIKI Class Facilities E-Complain adalah sebagai berikut:

\subsubsection{Halaman Login}

Halaman login merupakan halaman yang digunakan untuk mengaktifkan akses halaman pengelolaan sistem pada halaman berikutnya. Pada halaman login ini terdapat 1 hak akses yaitu hanya pada hak akses selaku admin. 


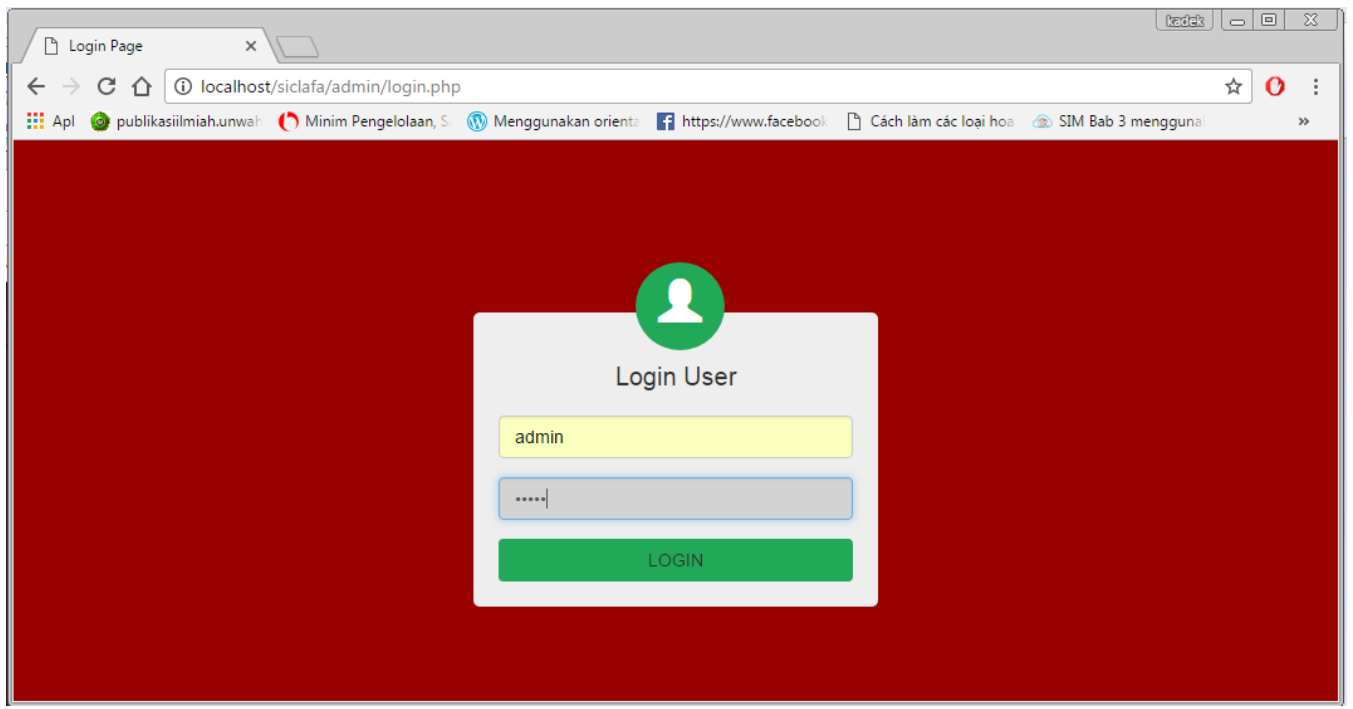

Gambar 5. Halaman Login

\subsubsection{Halaman Admin dan Halaman Denah Ruang}

Pada halaman admin berfungsi sebagai pengatur sistem informasi STIKI Class Facilities EComplain. Pada halaman admin terdapat menu untuk menampilkan halaman denah ruang dari daftar keluhan dosen, halaman pengaduan keluhan dosen, dan halaman daftar keluhan yang belum teratasi. Implementasi dari halaman admin, ditunjukkan pada Gambar 6. Pada halaman admin ini sekaligus menampilkan halaman denah ruang dari daftar keluhan dosen dalam bentuk notifikasi.

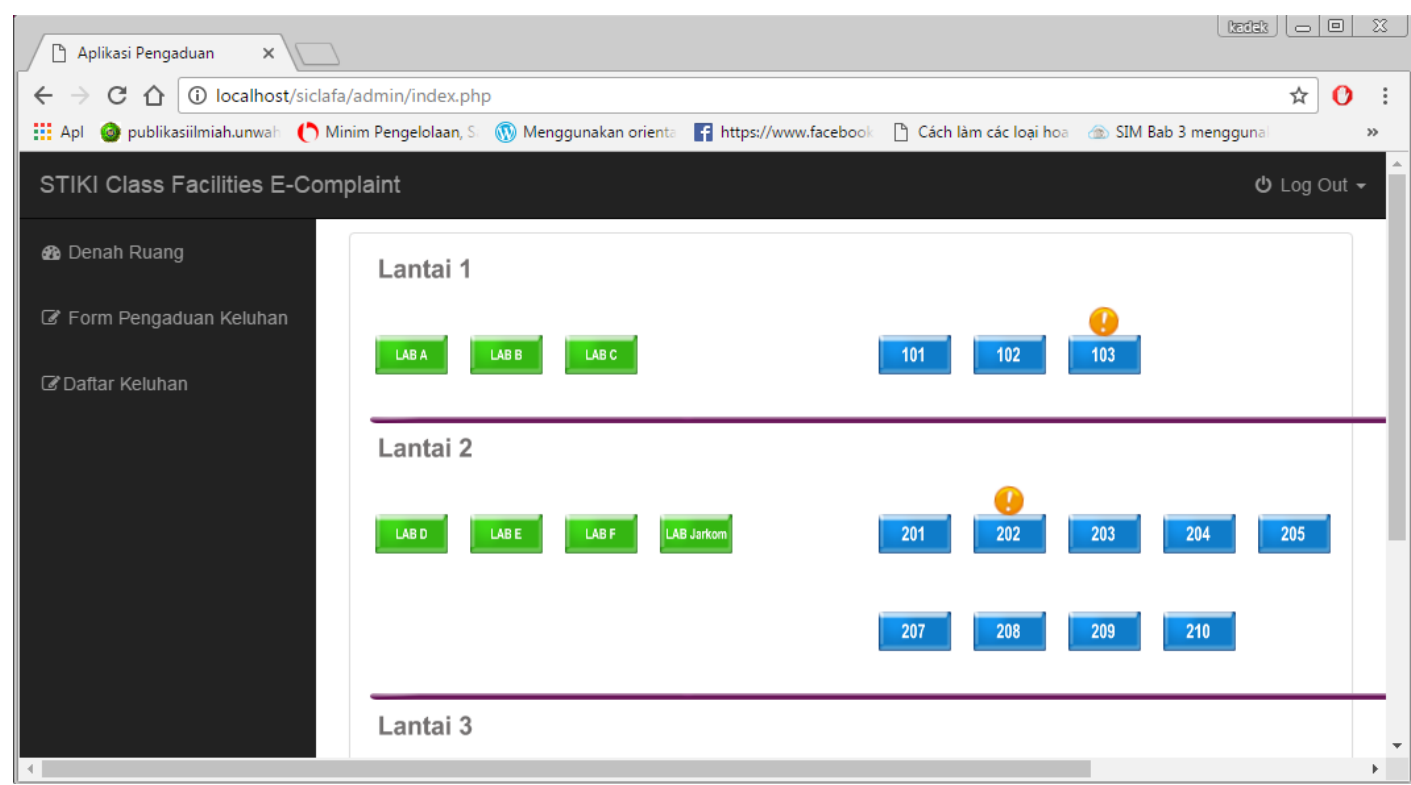

Gambar 6. Halaman Admin dan Halaman Denah Ruang

Pada Halaman denah ruang ini diperuntukkan untuk bagian Tata Laksana Rumah Tangga dan Perlengkapan selaku admin dan bagian Teknisi. Dimana halaman ini mempermudah pengamatan bagi bagian Tata Laksana Rumah Tangga dan Perlengkapan selaku admin dan bagian Teknisi untuk meninjau ruangan mana saja yang mengalami kendala atau kerusakan fasilitas yang akan digunakan oleh dosen. Informasi yang diberikan pada halaman denah ruang

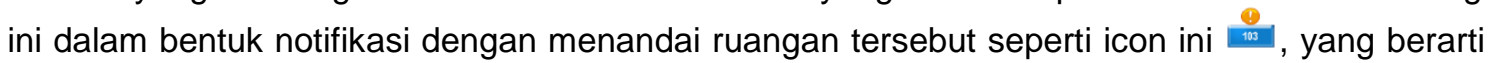
ruangan tersebut mengalami kendala. 


\subsubsection{Halaman Form Pengaduan Keluhan}

Untuk halaman form pengaduan keluhan ditujukan untuk dosen seperti pada Gambar 7. Pada halaman tersebut dosen dapat melakukan pengisian keluhan saat terjadinya kendala di saat berlangsungnya proses belajar dan mengajar. Adapun data yang diinputkan ke dalam halaman form pengaduan keluhan tersebut adalah nama dosen yang bersangkutan, nama ruangan disaat dosen mengajar, kriteria keluhan yang terdiri dari AC, Komputer, LCD dan LAN. Pada kriteria keluhan tersebut dengan mencamtumkan fasilitas yang sekiranya mengalami kerusakan Sedangkan detail keluhan adalah dosen memberikan keterangan kerusakan pada fasilitas yang dipilih sesuai dengan kriteria keluhan.

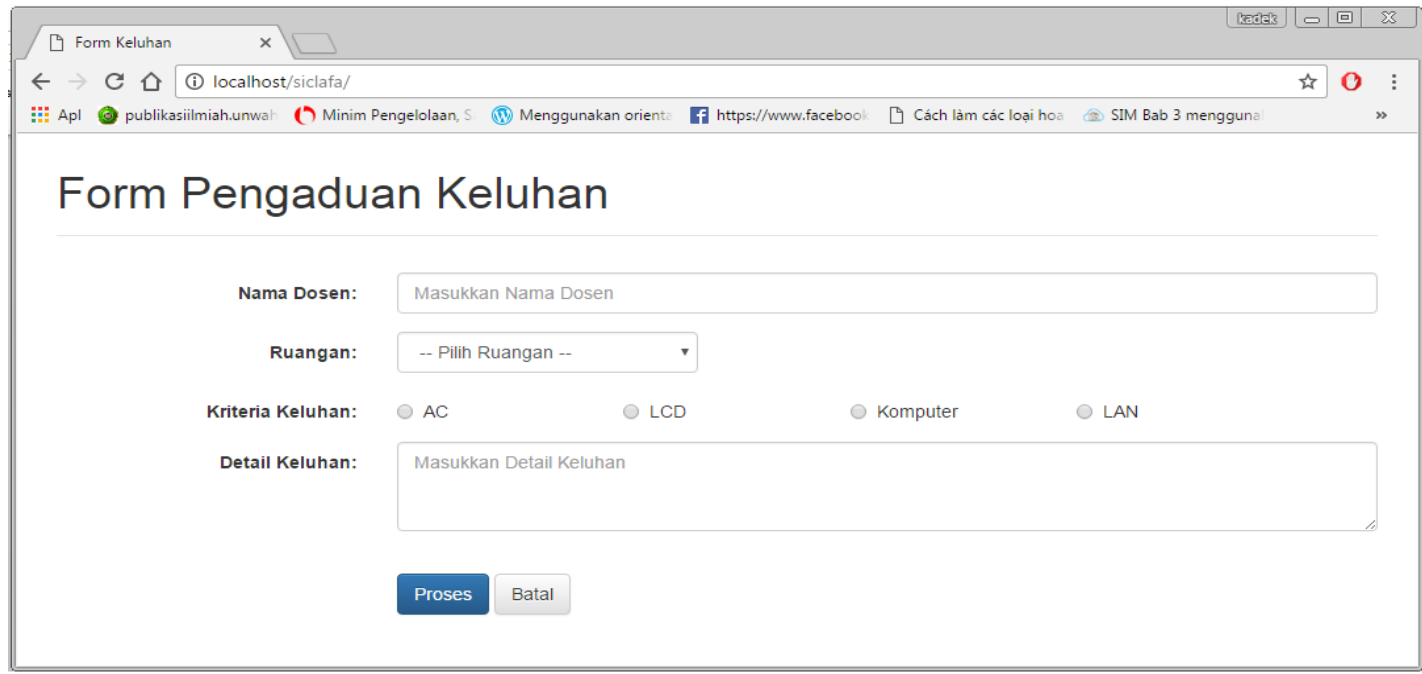

Gambar 7. Halaman Form Pengaduan Keluhan

\subsubsection{Halaman Daftar Keluhan yang Belum Teratasi}

Halaman Daftar Keluhan yang Belum Teratasi ditunjukkan pada Gambar 8. Pada halaman ini memuat informasi tentang daftar detail dari keluhan-keluhan terhadap ruangan yang belum teratasi oleh bagian Teknisi sehingga memudahkan bagian Tata Laksana Rumah Tangga dan Perlengkapan dapat memonitor kinerja dari bagian Teknisi.

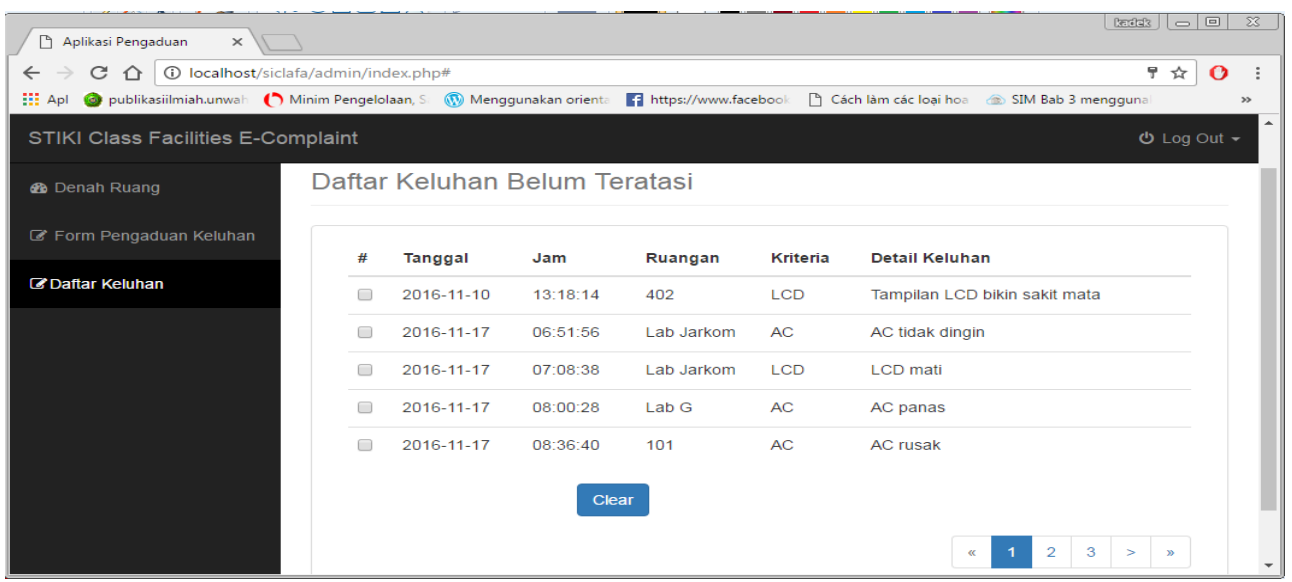

Gambar 8. Halaman Daftar Keluhan yang Belum Teratasi

\section{Kesimpulan}

Berdasarkan penelitian yang telah dilakukan dengan pemodelan prototipe dapat disimpulkan beberapa hal bahwa Sistem Informasi STIKI Class Facilities E-Complaint di STMIK STIKOM Indonesia dapat dibangun berbasis web sesuai dengan kebutuhan user itu sendiri dalam hal ini adalah bagian Tata Laksana Rumah Tangga dan Perlengkapan di STMIK STIKOM Indonesia 
serta bagian tersebut dapat memonitor kinerja teknisi dengan adanya informasi yang diberikan dalam notifikasi pada halaman denah ruang dari daftar keluhan dosen.

\section{Daftar Pustaka}

[1] L. Fajarita et al., "Analisa Dan Perancangan Sistem Informasi Penanganan Keluhan," in Sentika, 2015, pp. 231-236.

[2] I. D. Joni and I. K. Sandika, "Sistem Informasi Manajemen sebagai Alat Pengelolaan Penelitian Dosen," Lontar Komput. J. IIm. Teknol. Inf., vol. 7, no. 1, pp. 51-60, 2017.

[3] Basri and J. Devitra, "Analisis Dan Perancangan Sistem Informasi Pengelolaan Arsip Berbasis Web (Studi Kasus: Pada Komisi Pemilihan Umum (KPU) Kabupaten Tebo)," J. Manaj. Sist. Inf., vol. 2, no. 1, pp. 227-243, 2017.

[4] I. B. Gamaswara, O. Sudana, and N. M. I. Marini, "Perancangan Sistem Informasi Manajemen Modul Layanan Pada Rumah Sakit," Lontar Komput. J. IIm. Teknol. Inf., vol. 6, no. 3, pp. 163-174, 2015.

[5] G. S. Reddy, R. Srinivasu, S. R. Rikkula, and V. S. Rao, "Management Information System To Help Managers For Providing Decision Making In An Organization," Int. J. Rev. Comput., pp. 1-6, 2009.

[6] H. Jogiyanto, Analisis \& Desain Sistem Informasi: Pendekatan Terstruktur, Pertama. ANDI OFFSET, 1990.

[7] R. M. Jr, "Sistem Informasi Manajemen," in Jilid 2, Bahasa Ind., Sukardi Hardi, Ed. Jakarta: PT. Prenhallindo, 1996, p. 30.

[8] R. Dewi, "PELANGGAN DI PT TELEKOMUNIKASI INDONESIA Tbk," vol. 2012, no. semnasIF, pp. 52-58, 2012.

[9] Nugroho Adi, Perancangan dan Implementasi Sistem Basis Data. Yogyakarta: CV. ANDI OFFSET, 2011.

[10] Pressman Roger S, Rekayasa Perangkat Lunak. Yogyakarta: CV. ANDI OFFSET, 2002.

[11] S. R. Herdajanti and L. Erawan, "Rancang Bangun Situs Web Pengumpul Berita Dari Situs E-Government Menggunakan Teknologi RSS," Techno.COM, vol. 13, no. 3, pp. 179-188, 2014. 